\title{
Nordisk kriminalistmøte 2013 - Oslo 22.-24. august
}

Arrangementet gjennomføres på følgende steder i Oslo sentrum (se også vedlagte kart):

Torsdag: Håndverkeren Kurs- og Konferansesenter, Rosenkrantzgate 7

Mottakelse: Juridisk bibliotek i Domus Bibliotheca, Karl Johans gate 47

Fredag: Domus Nova, St. Olavs plass 5, rom 770 og Auditoriet $i$ 7. etg.

Lunsj: Scandic Edderkoppen, St. Olavs plass 1

Festmiddag: Bristol, Kristian IV's gate 7

Lørdag: Domus Nova, St. Olavs plass 5, rom 540, rom 543 og Auditoriet i 7. etg.

\begin{tabular}{|c|c|}
\hline Torsdag 22. august & HÅNDVERKEREN \\
\hline $11.00-$ & Registrering \\
\hline $13.15-13.30$ & Åpning \\
\hline $13.30-14.00$ & $\begin{array}{l}\text { Kriminalitet, kriminelle og kriminalister } \\
\text { riksadvokat Tor-Aksel Busch }\end{array}$ \\
\hline $14.30-15.30$ & $\begin{array}{l}\text { Kriminalistforeningens historie } \\
\text { seniorkonsulent Per Jørgen Ystehede (NO) }\end{array}$ \\
\hline $15.30-16.00$ & Kaffepause \\
\hline $16.00-17.00$ & $\begin{array}{l}\text { Principen om dubbel effekt i ett straffrättsligt perspektiv } \\
\text { professor Petter Asp (SE) }\end{array}$ \\
\hline $19.00-21.00$ & Mottakelse på juridisk bibliotek, Domus Bibliotheca \\
\hline Fredag 23. august & DOMUS NOVA \\
\hline \multicolumn{2}{|l|}{ 09.30-11.00 } \\
\hline $\begin{array}{l}\text { Sesjon I.A } \\
\text { Auditoriet i 7. etg. }\end{array}$ & $\begin{array}{l}\text { Hvordan straffes der for voldtagt? } \\
\text { professor Ragnheiður Bragadóttir (IS) } \\
\text { kommentator: statsadvokat Thomas Frøberg }\end{array}$ \\
\hline $\begin{array}{l}\text { Sesjon I.B } \\
\text { Rom } 770\end{array}$ & $\begin{array}{l}\text { Forsvarets bistand til politiet ved maktutøvelse, herunder } \\
\text { terrorbekjempelse, på norsk territorium - forholdet til Grunnloven } \\
\text { \$99 annet ledd } \\
\text { forsker Ragnar Auglend (NO) } \\
\text { kommentator: generaladvokat Arne Willy Dahl }\end{array}$ \\
\hline
\end{tabular}

$11.00-12.30$ 


\begin{tabular}{ll}
\hline $\begin{array}{l}\text { Sesjon II.A } \\
\text { Auditoriet i 7. etg. }\end{array}$ & $\begin{array}{l}\text { 22. juli-rapporten: Politiet som lærende organisasjon } \\
\text { professor Liv Finstad (NO) } \\
\text { kommentator: politimester Hans Sverre Sjøvold }\end{array}$ \\
\hline $\begin{array}{l}\text { Sesjon II.B } \\
\text { Rom 770 }\end{array}$ & $\begin{array}{l}\text { Administrative sanksjoner - oppfølgingen av Sanksjonsutvalgets } \\
\text { utredning } \\
\text { lovrådgiver Arnulf Tverberg (NO) } \\
\text { kommentator: lagdommer Hans-Petter Jahre }\end{array}$ \\
\hline $12.30-14.00$ & Lunsj-Scandic Edderkoppen \\
\hline
\end{tabular}

$14.00-15.30$

Sesjon III.A Hvornår og hvordan straffer vi skattesnyderne?

Auditoriet i 7. etg. professor Gorm Toftegaard Nielsen (DK) kommentator: avdelingsdirektør Knut Erik Omholt

Sesjon III.B

Rom 770

Kriminaliteten og mediene

professor Sigurd Allern (NO)

kommentator: statsadvokat Inga Bejer Eng

\section{$15.30-17.00$}

Sesjon IV.A

Auditoriet i 7. etg.

22. juli-rettssaken. Hvorfor gikk det så bra? Og hvordan kan de gode losninger få modellmakt?

professor emeritus Nils Christie (NO)

kommentator: førstestatsadvokat Terje Nybø

Sesjon IV.B

»The Golden Age of Nordic Cooperation«

Rom 770

Har de nordiska kronjuvelerna kommit på museum?

Den nordiska brottskontrollen - nutid, dåtid och framtid

professor Per Ole Träskman (SE)

Kommentator: lovrådgiver Ingeborg H. Olebakken

19.00- Festmiddag - Bristol

\section{Lordag 24. august DOMUS NOVA}

09.30-11.00

Sesjon V.A

Kriminalitetens velsignelser

Auditoriet i 7. etg. professor Alf Petter Høgberg (NO)

kommentator: ØKOKRIM-sjef Trond Eirik Schea

Sesjon V.B Særreaksjoner i komparativt lys

Rom $540 \quad$ stipendiat Simon Engell Kamber (DK)

kommentator: førstestatsadvokat Berit Sagfossen (NO)

Sesjon V.C Familievold

Rom $543 \quad$ professor Linda Gröning (NO/SE)

kommentator: advokat John Christian Elden 


$\begin{array}{ll}\text { 11.00-12.30 } & \text { Paneldebatt og avslutning } \\ \text { Auditoriet i 7. etg. } & \text { Ytringsfrihetens og integritetens kår på følsomme områder } \\ & \text { - religions- og kulturkritikk vs. blasfemi og rasisme } \\ & \text { stipendiat Anine Kierulf } \\ & \text { post doktor Sindre Bangstad } \\ & \text { generalsekretcer Nils E. Øy } \\ & \text { førstekonsulent Runa Gravensteen } \\ & \text { professor Gorm Toftegaard Nielsen } \\ & \text { ordstyrer: stipendiat Jørgen A. Stubberud }\end{array}$

